\author{
Колесник B.I. \\ кандидат економічних наук, доцент \\ кафедра управління бізнесом \\ Одеська національна академія харчових технологій \\ вул. Канатна, 112, м. Одеса, Україна, 65039 \\ E-mail: brig_od@i.ua \\ ORCID ID: 0000-0003-3603-1303
}

\title{
СТИМУЛЮВАННЯ ТВОРЧОЇ ПРАЦІ ПЕРСОНАЛУ ЯК ФАКТОР ПІДВИЩЕННЯ ІНВЕСТИЦІЙНОЇ ПРИВАБЛИВОСТІ ПІДПРИЄМСТВ ХАРЧОВОЇ ПРОМИСЛОВОСТІ
}

\begin{abstract}
Стаття розглядає актуальні питання управління творчою працею, зокрема її стимулювання як фрактор підвищення інвестиційної привабливості на підприємствах харчової промисловості. В статті проаналізовано сутність творчої праці як категорії управлінської науки, основні ознаки творчої праці, в тому числі порівняно до інших видів енергії охарактеризована духовна енергія як основа та джерело творчої праці. Визначаються проблеми науки та практики менеджменту відносно стимулювання творчої праці, серед яких виокремлено проблеми якості професійної управлінської компетенції, недиференційованого підходу до стимулювання творчої праці, проблему системності й науковості в практичній роботі з персоналом творчої праці. Запропоновано системний підхід до стимулювання творчої праці, який передбачає з одного боку створення сприятливого середовища для генерації духовної енергії персоналу, а з іншого - баланс технізації виробництва, мета якого - оптимізація використання різних типів енергії (праці) у виробництві.
\end{abstract}

Ключові слова: творча праця, духовна енергія, управління творчою працею, стимулювання творчої праці, інвестиційна привабливість.

This work is licensed under a Creative Commons Attribution 4.0 International License http://creativecommons.org/licenses/by/4.0/

Постановка проблеми та їі зв'язок з важливими науковими та практичними завданнями. Непересічні ринкові трансформації сьогодення, зовнішньоекономічні та політичні виклики актуалізують дослідження інвестиційної привабливості як національної економіки загалом, так і однієї з підвалин сталого розвитку держави - підприємств харчової промисловості. Проблематика наукового та методологічного рівня вказує на те, що з одного боку спостерігається дефіцит системних досліджень, які б розглядали саме творчу працю персоналу як фактор інвестиційної привабливості підприємства, а з іншого - практика господарювання показує неможливість досягнення певного рівня інвестиційної привабливості виключно за рахунок фактору технізації виробництва. Стратегічно важливого значення в даному контексті набувають технології керування людьми, а також їх творчою працею.

Аналіз останніх публікацій по проблемі. Деякі аспекти творчої праці висвітлено в дослідженнях К. Бреді, Д. Гоумлана, В. Іноземцева, Дж. Маєра, П. Саловея, Дж. Аткінсона, А. Колота, С. Коваленко, Е. Кузнецова. Чимало плідних робіт I. Адізеса, Д. Гілфорда, Н. Іванцової, В. Роменець та інших авторів стосуються психологічних питань професійної спрямованості, місця творчості в процесі реалізації професійного потенціалу тощо. Проте, враховуючи тен- денції розвитку науки та практики управління, технологій, наразі особливо актуальним $є$ розгляд такого інструменту менеджменту як стимулювання творчої праці персоналу в площині його впливу на інвестиційну привабливість підприємств харчової промисловості.

Формулювання цілей дослідження. Систематизувати коло теоретико-практичних проблем стимулювання творчої праці персоналу; уточнити зміст та роль творчої праці в системі функціонування підприємства; дослідити проблематику впливу стимулювання творчої праці на інвестиційну привабливість підприємств харчової промисловості.

Виклад основних результатів та їх обгрунтування. Необхідною передумовою даного дослідження $є$ уточнення поняття «творча праця», пояснення тематично-пов'язаних категорій.

Оскільки центральним поняттям, що власне виділяє працю в творчу - $\epsilon$ «творчість», необхідно уточнити зміст даної категорії. 3-поміж великої кількості визначень творчості, даних представниками різних областей знань, комплексністю вирізняється визначення В. Іноземцева, згідно якого творчість трактується як процес, всередині котрого набуває реалізації внутрішньоспонукальний мотив діяльності. Таке бачення підкреслює, що головним моментом процесу $\epsilon$ не лише матеріально-речовий результат, але й 
удосконалення людських здібностей, а основні відмінності творчої праці від нетворчої лежать в площині внутрішніх мотивів і в структурі діяльності. Така діяльність $\epsilon$ винятково індивідуальною, як за ії мотивацією і засобами втілення, так і за результатами.

Науково-практична користь вищенаведеного тлумачення творчості може бути доповнена:

1. Творчість є складним процесом, який за умов цілеспрямованої діяльності груп людей, об'єднаних певним діловим підприємством, потребує керування і спеціальних системних технологій менеджменту. 2. Оскільки головним моментом даного процесу є не лише матеріально-речовий результат, а й людські здібності, внутрішні мотиви учасників праці тощо - основою творчої праці виступає система цінностей підприємства, відображена у відповідних елементах (місія, бачення, корпоративна культура, стратегічні пріоритети) і гармонізована 3 цінностями персоналу. 3. Об'єктом управління у випадку управління творчою працею персоналу залишається людина та їі особливі види енергії, незалежно від виконуваної роботи, специфіки виду економічної діяльності підприємства тощо. Звідси можна навести доповнене визначення творчої праці - це цілеспрямована, глибоко індивідуалізована як за мотивацією, так і за засобами реалізації діяльність, урухомлювана духовною енергією людини з метою досягнення певних соціальноекономічних результатів. Дане визначення показує деякі ключові ознаки творчої праці, котрі мають принципове значення для розуміння природи цього виду праці та для опрацювання ефективного інструментарію iї стимулювання. Насамперед, потрібно підкреслити, що різним видам праці відповідають певні види людської енергії, які в свою чергу потребують різних умов для своєї активізації. Крайніми позиціями в даному випадку $є$ ступінь примушення або ступінь свободи. Чим вище рівень введеної в дію людської енергії, тим більшою повинна бути ступінь свободи і тим більше примушення слід замінити спонуканням. Високі рівні енергії та відповідні види праці передбачають надання персоналу більшої самостійності, а термінологія менеджменту це виражає делегуванням повноважень від керівника до виконавця $[3,43]$. Таблиця 1 відображає відповідність та взаємний зв'язок різних видів праці, видів людської енергіï, їх аналогів в живій природі й умов реалізації на підприємстві.

Таблиця 1

Співвідношення людської енергії, видів праці та аналогу людської енергії [3, 43]

\begin{tabular}{|c|c|c|c|}
\hline Вид енергії & Вид праці & Аналог людської енергії & Умови реалізації \\
\hline Мускульна & Тяжка фізична & $\begin{array}{l}\text { Природна електрична енер- } \\
\text { гія. Процес трансформації } \\
\text { даного виду енергії назива- } \\
\text { ють механізацією праці }\end{array}$ & \multirow[t]{5}{*}{$\begin{array}{c}\text { Примушення, спо- } \\
\text { нукання }\end{array}$} \\
\hline Нервова & Легка фізична & $\begin{array}{l}\text { Також електрична енергія, } \\
\text { але вже } 3 \text { елементами елек- } \\
\text { троніки. Вона створює ос- } \\
\text { нову для автоматизації пра- } \\
\text { ці }\end{array}$ & \\
\hline Логічна & Проста розумова & $\begin{array}{l}\text { Розвиток електроніки приз- } \\
\text { вів до комп'ютеризації пра- } \\
\text { ці }\end{array}$ & \\
\hline Інтелектуальна & Складна розумова & $\begin{array}{l}\text { Створення на базі електро- } \\
\text { ніки } 3 \text { елементами біотехно- } \\
\text { логії штучного інтелекту }\end{array}$ & \\
\hline Духовна & Творча & Аналогу сьогодні немає & \\
\hline
\end{tabular}

Інформація, наведена в таблиці 1 дає можливість зазначити, що загальний закон делегування енергії в системі менеджменту виглядає як закон делегування повноважень, рушійною силою якого $\epsilon$ закон, діючий за умов конкурентного ринкового механізму закон економії часу (праці). Тому менеджмент повинен керуватися тим, що чим вищим є індустріальнолюдський енергетичний потенціал, задіяний підприємством, тим ефективнішим можна назвати його функціонування, підвищуючи тим самим свій рівень конкурентоспроможності й водночас набуваючи більшої інвестиційної привабливості. Дане твердження $\epsilon$ принциповим, індиферентним до галузевої спеціалі- зації підприємства, а отже справедливим і для підприємств харчової промисловості.

Вищенаведені ознаки творчої праці та характеристика іiі соціально-економічної природи уможливлюють аналіз стимулювання творчої праці персоналу в площині його впливу на інвестиційну привабливість підприємства. При цьому, перш за все привертає увагу низка проблем:

1. Рівень професіоналізації менеджменту підприємства. Оскільки персонал - керована підсистема, а менеджмент - керуюча, необхідною передумовою реалізації будь-яких методів стимулювання праці $\epsilon$ наявність достатньої професійної управлінської ком- 
петенції керівників. Мова йде про об'єктивну складність адміністрування творчої праці. Наприклад, так як в основі творчої праці духовна енергія людини це призводить до проблем кількісного виміру ефективності такої праці, тайм-менеджменту (дія стимулу та кінцевий цільовий результат творчої праці можуть значно різнитися за часом) тощо. Більш того, часові рамки появи нового творчого продукту слабо піддаються плануванню, що відображається на всьому ланцюжку управлінських дій і вимагає від керівника неабияких зусиль, майстерності та того ж творчого підходу до керування у вигляді відповідних інноваційних управлінських технологій для роботи з персоналом.

Ця ж проблема є джерелом ненаукового підходу до організації системи стимулювання творчої праці на підприємстві.

2. Диференційований підхід до стимулювання творчої праці. Це стосується з одного боку, диференційованого застосування методів стимулювання по відношенню до конкретного працівника, специфіки виконуваного проекту, часового проміжку, типу виконуваної праці тощо, а 3 іншого - диференціації спеціальних методів стимулювання залежно від місця працівника в структурі підприємства (управлінський персонал чи неуправлінський) i також в ієрархії управління (вищий рівень, середній, лінійний рівень у випадку управлінського персоналу). Загальні тенденції $є$ такими, що місця для творчої праці більше на вищих рівнях ієрархії управління. Функціональні ділянки насичені можливостями для творчої праці порізному залежно від галузевої специфіки підприємства - відповідно і управлінська робота повинна бути скерована або на спонукання чіткого виконання інструкцій (в даному випадку якраз на обмеження творчості), або на стимулювання творчої праці відповідними методами.

3. Науковість застосовуваних методів стимулювання праці. Криза вітчизняної управлінської науки унеможливлює прогрес та поширення ефективних розробок в даному напрямку. Професійні зв'язки між підприємствами харчової промисловості (особливо малими та середніми) з науковими установами практично відсутні. Дещо краща ситуація в цьому плані на великих підприємствах, які стали частиною світових корпорацій (наприклад, фабрики «Nestle», «PepsiCo», «Unilever») та які мають налагоджену систему управління відповідно високих стандартів менеджменту. Компанії на кшталт наведених вище мають окремі підрозділи з управління талантами, оргструктура яких в свою чергу передбачає спеціалізацію управлінського персоналу на стимулюванні творчої праці, ऑii адмініструванні, а також реалізації інших функцій по управлінню персоналом включно з творчою працею, знаннями, роботі з емоційним інтелектом тощо. Надважливу роль при цьому відіграють корпоративні університети, які можуть бути джерелом власних наукових розробок, адаптованих під специфіку діяльності та потреби підприємства. Робота ж в цьому напрямку на малих та середніх підприємствах залежить від професійної волі, бажання та наявної професійної компетенції окремо взятого керівника, як правило, не претендує на системну та науковообгрунтовану і являє собою набір матеріальних й подекуди нематеріальних методів стимулювання праці.

4. Системний підхід до управління інвестиційною привабливістю. Системно - значить за допомогою всієї сукупності елементів підприємства як відкритої соціо-технічної системи. Враховуючи тренди високої технізації підприємств харчової промисловості, підсвідомі (часто помилкові) кореляції менеджменту на кшталт «новітнє обладнання - апріорі більш інвестиційно привабливе підприємство», потрібно зауважити, що саме люди є носіями унікального типу духовної енергї - джерела творчої праці, яка в свою чергу слугує джерелом інноваційного підходу до роботи i, як наслідок, конкурентоспроможності й інвестиційної привабливості. Духовна енергія - складне та неоднозначне навіть для сучасної науки поняття. Проте можна стверджувати, що генерує даний тип енергії спілкування кількох людей на певну тему за відповідного середовища. Такий хід думок вказує на певні обмеження технікою та машинами людського спілкування (зокрема для прийняття рішень, генерації нового знання тощо), а значить і обмежує застосування в праці духовної енергії, заміняючи їі іншими видами енергії (електронікою, штучним інтелектом). Тобто якщо творча праця персоналу передбачає вихід думок за межі звичних рішень, погляд на проблему під іншим кутом, то технізація виробництва навпаки - крок до шаблонності, стандартів та типових рішень. Звісно обидва підходи мають свої переваги та недоліки, але основне завдання менеджменту за даних обставин, вбачається в уникненні крайніх позицій, знаходженні оптимальних пропорцій і відповідних місць на підприємстві, де використання того чи іншого типу енергії (праці) у виробництві було б максимально ефективним та наближало підприємство до цільових показників інвестиційної привабливості. 3 іншого боку системність означає поступовість в часі. В цьому сенсі потрібно погодитись 3 японським керівником А. Морітою, за словами якого стимулювання творчих здібностей працівників є наступним кроком після того, як сформовано штат компетентних, розумних і здібних людей $[6,59]$. За Морітою, творча праця - це з одного боку противага інструкціям (хоча він вважає, що і такі високо регламентовані процедури, як системи контролю якості - теж результат творчої праці персоналу корпорації «Sony»), а 3 іншого це спочатку все ж таки навчання і наслідування. Виходячи 3 даних думок, на початковому етапі організації творчої праці всю велику кількість методів вирішення творчих завдань доцільно представити таким інструментарієм для керівника: а) логічні методи методи в яких переважають логічні правила аналізу (порівняння, узагальнення, класифікації, індукції, дедукції); б) евристичні методи (синектики, мозкового штурму, ключових запитань, багатомірних матриць). Даний підхід може слугувати взірцем в організації управління творчою працею. 
Висновки та перспективи подальших досліджень. Дане дослідження дає змогу зробити наступні висновки:

- творча праця - складний для управління тип праці, проте - це необхідний чинник розвитку сучасного підприємства харчової промисловості, який 3 одного боку не гарантує досягнення бажаного рівня інвестиційної привабливості, проте з іншого - стимулювання праці такого типу за умов сьогодення $\epsilon$ необхідним елементом уваги менеджменту;

- серед чисельних ознак творчої праці - ключовим вбачається за доцільне вважати саме духовну енергію людини, яка дозволяє віднайти нестандартне вирішення, поглянувши на досліджуваний об'єкт під нетиповим кутом зору. В табл. 1 даного дослідження систематизовано погляд на різні види енергії та праці персоналу, 3 якими має справу керівник; наведено аналоги людської енергії в природі, яким можна делегувати певну роботу та наведено організаційні умови- відповідники тому чи іншому типу праці (енергії);

- творча праця потребує управління загалом та стимулювання зокрема. Немає сенсу вести мову про застосування певного методу, який був би ефективним в тій чи іншій ситуації. Стимулювання творчої праці являє собою постійний у часі, диференційований та системний за організацією процес, який допускає можливість застосування загальнонаукових методів для генерації альтернатив («мозковий штурм», метод «ключових питань», багатомірних матриць тощо), проте в той же час передбачає подальший індивідуальний підхід до конкретного працівника;

- мету дослідження досягнуто. Перспективами подальших досліджень $є$ питання управління інноваційним мисленням, емоційним інтелектом керівників як чинником впливу на інвестиційну привабливість підприємства.

\section{Лiтература}

1. Гоулман Д. Емоційний інтелект / Гоулман Деніел; пер. з англ. С.-Л. Гумецької. Х.: Віват, 2019. 512 с.

2. Данилевич Н. Шляхи вдосконалення системи мотивування в процесі управління персоналом підприємства // Психологічні виміри культури, економіки, управління. 2018. № XI. C. 102-118.

3. Кузнецов Е.А. Професіоналізація управлінської діяльності: система, механізм та інноваційна динаміка: монографія. Одеса: Наука і техніка, 2015. 368 с.

4. Лалу Ф. Компанії майбутнього / Лалу Ф.; пер. з англ. Р. Клочко. Харків: КСД, 2017. 544 с. (укр. м.).

5. Лисак В.Ю. Управління і мотивація персоналу переробно-харчових підприємств: зарубіжні інновації та вітчизняна практика // Вісник Сумського національного аграрного університету. Сер. Фінанси і кредит. 2011. №1. C. 11-14.

6. Моріта A. Sony - сделано в Японии / Морита Акио.; пер. с англ.: О. Радынова, С. Щеглов. Альпина Паблишер, 2018. 288 c.

7. Назаришин Р. Фундаментальні поняття мотиватики як науки про мотивацію праці // Україна: аспекти праці. 2013. № 3. С. 38-42. (укр. м.)

8. Партридж Д. Люди чи прибуток / Партридж Д.; пер. з англ. Н. Палій. К.: КНИГОЛАВ, 2017. 240 с.

9. Роменець В.А. Психологія творчості. К.: Вища школа, 1971. 248 с.

10. Солодуха О.В. О необходимости развития инновационного мышления в менеджменте // Современные информационные технологии в экономике и управлении предприятиями, программами и проектами: материалы VIII Международной научно-практической конференции. Харьков «ХАИ», 2010. С. 57-59

11. MacLachan Rob. The Pioneers who Put People First. People Management, 1995. 233 p.

Стаття надійшла 21.04.2020

Стаття прийнята до друку 5.05.2020

Доступно в мережі Internet 11.07.2020

Колесник В.И

кандидат экономических наук, доцент кафедра управления бизнесом

Одесская национальная академия пищевых технологий ул. Канатная, 112, м. Одеса, Украина, 65039

E-mail: brig_od@i.ua

ORCID ID: 0000-0003-3603-1303

\section{СТИМУЛИРОВАНИЕ ТВОРЧЕСКОГО ТРУДА ПЕРСОНАЛА КАК ФАКТОР ПОВЫШЕНИЯ ИНВЕСТИЦИОННОЙ ПРИВЛЕКАТЕЛЬНОСТИ ПРЕДПРИЯТИЙ ПИЩЕВОЙ ПРОМЫШЛЕННОСТИ}

Статья рассматривает вопросы теории и практики стимулирования творческого труда как фрактора повышения инвестиционной привлекательности предприятий пищевой промышленности. В ста- 
тье поднимаются актуальные проблемы, являющиеся следствием непрофессионального стимулирования творческого труда, вызванные среди прочего непростой ситуацией в украинской науке и практике менеджмента, а также тем, что существующие научно-практические наработки не всегда пригодны для применения в современных условиях хозяйствования. Основываясь на мнениях отечественных и зарубежных ученых, описываются основные признаки творческой деятельности, а именно то, что в ее основе духовная энергия человека. Приводится сравнительная характеристика всех видов труда и энергии, которые применяются на предприятии, а также их аналоги в природе, которым менеджеры могут делегировать ту или иную работу. Анализ основных проблем стимулирования творческого труда в контексте влияния этого фактора на инвестиционную привлекательность предприятий, позволил предложить инновационный подход к соответствующей организации системы менеджмента. Ключевые положения данного подхода таковы:

- первостепенной задачей менеджмента в данном контексте есть создание соответствующих условий для генерации и воспроизведения духовной энергии персонала, аналога которой на сегодня нет;

- необходима интеграция функции стимулирования с другими функциями менеджмента - она не может работать обособленно;

- необходимо избежание крайних позиций относительно технизации производства, поскольку делегирование технике задач может быть угрозой коммуникации персонала, процесс которой можно считать предпосылкой духовной энергии человека и, как следствие - необходимым условием творческого труда;

- стимулирование творческого труда требует системности, которая выражается, прежде всего, в формировании определенных стандартов профессионального обучения персонала, что является основой творческой работы;

- важна система коммуникации между персоналом и менеджментом фрирмы. Преимуществом данного подхода можно назвать системность и безразличие к специфике вида экономической деятельности предприятия.

Ключевые слова: творческий труд, духовная энергия, управление творческим трудом, стимулирование творческого труда, инвестиционная привлекательность.

\author{
Kolesnyk V. \\ Ph.D., Associate Professor \\ Department of Business Administration \\ Odessa National Academy of Food Technologies \\ Kanatna str., 112, Odesa, Ukraine, 65039 \\ E-mail: brig_od@i.ua \\ ORCID ID: 0000-0003-3603-1303
}

\title{
STIMULATION OF CREATIVE WORK OF PERSONNEL AS A FACTOR FOR INCREASING THE INVESTMENT ATTRACTIVENESS AT FOOD INDUSTRY ENTERPRISES
}

The article deals with the problems of stimulating the creative work of personnel as a factor for increasing the investment attractiveness at food industry enterprises. The article considers problems that rise as a result of use of non professional technologies of stimulating the creative work, caused in particular by the difficult situation in Ukrainian management science and practice of management. Therefore, knowledge and scientific developments regarding previous years in the field of creative work of management can't always be used in the conditions of the business today. Based on the opinions of Ukrainian and foreign scientists, some analytical information we have analyzed the specific features of the creative work as a management category as well as functioning and efficiency of traditional amauteur practice of Ukrainian "managers". The origin of the most urgent problems related with the present creative work processes (with the food industry examples) has been discussed. The nature of each problem has been given the likely causes and has been commented on. The analysis of these problems allowed to form an innovative approach to find ways of increasing management efficiency of stimulating the creative work of personnel, which will improve the investment attractiveness of business. Key positions of this approach are:

- the main goal of management in the given context is to create the best conditions for spiritual energy of personnel, the analogue of which doesn't exist now;

- use of main stimulating principles such as integration with other functions of management, differentiation and priority using for managers; 
- use of necessary tools from the professional system of management which allow to avoid exceeding technologization, because people's communication is necessary for creative work;

- formation of some standards of professional management education, which will allow to approach the issues of high quality stimulating of creative work systems systematically;

- creation of a mechanism of effective interaction between management and personnel. The advantages of this approach are that it is systematic and there is indifference to the industry division, which makes it useful for any relations as well as for creative activity between managers and personnel including the food industry sector.

Key words: creative work, spiritual energy, creative work management, stimulation of creative work, investment attractiveness.

\section{References}

1. Houlman, D. (2019). Emotsiinyi intelekt. (S.-L. Humetskoi, Trans.). Kh.: Vivat.

2. Danylevych, N. (2018). Shliakhy vdoskonalennia systemy motyvuvannia v protsesi upravlinnia personalom pidpryiemstva. Psykholohichni vymiry kultury, ekonomiky, upravlinnia, (XI), 102-118.

3. Kuznetsov, E. A. (2015). Profesionalizatsiia upravlinskoi diialnosti: systema, mekhanizm ta innovatsiina dynamika. Odesa: Nauka i tekhnika.

4. Lalu, F. (2017). Kompanii maibutnoho. (R. Klochko, Trans.). Kharkiv: KSD.

5. Lysak, V. Yu. (2011). Upravlinnia i motyvatsiia personalu pererobno-kharchovykh pidpryiemstv: zarubizhni innovatsii ta vitchyzniana praktyka. Visnyk Sumskoho natsionalnoho ahrarnoho universytetu, (1), 11-14.

6. Morita, A. (2018). Sony - sdelano v Yaponii. (O. Radyinova, \& S. Scheglov, Trans.). Alpina Pablisher.

7. Nazaryshyn, R. (2013). Fundamentalni poniattia motyvatyky yak nauky pro motyvatsiiu pratsi. Ukraina: aspekty pratsi, (3), 38-42.

8. Partrydzh, D. (2017). Liudy chy prybutok. (N. Palii, Trans.). Kyiv: KNYHOLAV.

9. Romenets, V. A. (1971). Psykholohiia tvorchosti. Kyiv: Vyshcha shkola.

10. O neobhodimosti razvitiya innovatsionnogo myishleniya v menedzhmente. (2010). In Sovremennyie informatsionnyie tehnologii v ekonomike i upravlenii predpriyatiyami, programmami i proektami: materialyi VIII Mezhdunarodnoy nauchno-prakticheskoy konferentsii (pp. 57-59). Harkov «HAI».

11. MacLachan, R. (1995). The Pioneers who Put People First. People Management.

Received 21 April 2020

Approved 5 May 2020

Available in Internet 11.07.2020

Цитування згідно ДСТУ 8302:2015

Колесник В.І. Стимулювання творчої праці персоналу як фактор підвищення інвестиційної привабливості підприємств харчової промисловості // Економіка харчової промисловості. 2020. Т. 12, Вип. 2. С. 62-67. doi:

10.15673/fie.v12i2.1741

Cite as APA style citation

Kolesnyk, V. (2020). Stimulation of creative work of personnel as a factor for increasing the investment attractiveness at food industry enterprises. Food Industry Economics, 12(2), 62-67. doi: 10.15673/fie.v12i2.1741 